Int. J. Dev. Biol. 57: 141-151 (2013)

doi: $10.1387 / \mathrm{ijdb} .130022 \mathrm{er}$

\title{
Expression of FGFR3 during human testis development and in germ cell-derived tumours of young adults
}

\author{
KATHERINE A. EWEN ${ }^{1}$, INGE A. OLESEN ${ }^{1}$, SOFIA B. WINGE ${ }^{1}$, ANA R. NIELSEN ${ }^{1}$, \\ JOHN E. NIELSEN ${ }^{1}$, NIELS GRAEM ${ }^{2}$, ANDERS JUUL ${ }^{1}$ and EWA RAJPERT-DE MEYTS ${ }^{*}, 1$ \\ 'Department of Growth \& Reproduction and 'Department of Pathology, Rigshospitalet, Faculty of Health Sciences, \\ University of Copenhagen, Copenhagen, Denmark
}

\begin{abstract}
Observations in patients with an activating mutation of fibroblast growth factor receptor 3 (FGFR3) suggest a role for FGFR3 signalling in promoting proliferation or survival of germ cells. In this study, we aimed to identify the FGFR3 subtype and the ontogeny of expression during human testis development and to ascertain whether FGFR3 signalling is linked to germ cell proliferation and the pathogenesis of testicular germ cell tumours (TGCTs) of young adult men. Using RT-PCR, immunohistochemistry and Western blotting, we examined 58 specimens of human testes throughout development for FGFR3 expression, and then compared expression of FGFR3 with proliferation markers (PCNA or Ki67). We also analysed for FGFR3 expression 30TGCTs and 28 testes containing the tumour precursor cell, carcinoma in situ (CIS). Fetal and adult testes expressed exclusively the FGFR3IIIc isoform. FGFR3 protein expression was restricted to the cytoplasm/plasma membrane of spermatogonia and was most prevalent at mid-gestation, infancy and from puberty onwards. Phosphorylated (p)FGFR was detected in pre-spermatogonia at mid-gestation and in spermatogonia during puberty and in the adult testis. Throughout normal human testis development, expression of FGFR3 did not directly correlate with proliferation markers. In preinvasive CIS cells and in TGCTs, including classical seminoma and embryonal carcinoma, FGFR3Illc was detected only in a small number of cells, with a heterogeneous expression pattern. FGFR3 is an excellent marker for human pre-/spermatogonia throughout development. Signalling through this receptor is likely associated with spermatogonial survival rather than proliferation. FGFR3 is not expressed in gonocytes and may not be essential to the aetiology of TGCTs stemming from CIS.
\end{abstract}

KEY WORDS: FGFR3, testis, carcinoma in situ, testicular neoplasm, germ cell

\section{Introduction}

Fibroblast growth factor receptor 3 (FGFR3) signalling appears to have an essential but as yet undetermined role in testicular germ cell biology. In other cell systems, FGFR signalling has diverse roles in regulating proliferation, survival, migration and differentiation during embryonic and postnatal development, and during tissue repair and response to injury (Harada et al., 2009). FGFR3 is one of four tyrosine kinase receptors, which can mediate signalling of a host of different FGFs (Lee et al., 1989; Johnson \& Williams 1992). In FGFR1-3 (but not FGFR4), tissue-specific alternative mRNA splicing of immunoglobulin (lg)-like domains produces epithelial 'b' and mesenchymal 'c' isoforms (Johnson et al., 1991; Johnson \& Williams 1992; Orr-Urtreger et al., 1993).
FGFR3 negatively regulates bone growth, and is necessary for correct craniofacial, skeletal, skin and ear development in humans. Mutations in the FGFR3gene can cause several forms of dwarfism, including achondroplasia (G380R) and thanatophoric dysplasia type II (K650E), and can also result in other disorders, such as Crouzon syndrome, craniosynostosis, acanthosis nigricans and hearing loss (Wilkie 2005; Robin et al., 2008/2011). Somatically arising FGFR3-activating mutations that match the germline mutations in the skeletal disorders have been linked with tumourigenesis, including bladder and cervical carcinoma, and multiple myeloma (Chesi et al., 1997; Richelda et al., 1997; Cappellen et al., 1999;

Abbreviations used in this paper: CIS, carcinoma in situ; FGFR3, fibroblast growth factor receptor 3; IHC, immunohistochemistry; TGCT, testicular germ cell tumour.

\footnotetext{
*Address correspondence to: Ewa Rajpert-De Meyts. Rigshospitalet, Section GR-5064, Blegdamsvej 9, DK-2100 Copenhagen, Denmark.

Tel: +45-3545-5017. Fax: +45-3545-6054. E-mail: erm@rh.dk
}

Supplementary Material (one figure) for this paper is available at: http://dx.doi.org/10.1387/ijdb.130022er

Final, author-corrected PDF published online: 5 June 2013.

ISSN: Online 1696-3547, Print 0214-6282

(C) 2013 UBC Press

Printed in Spain 


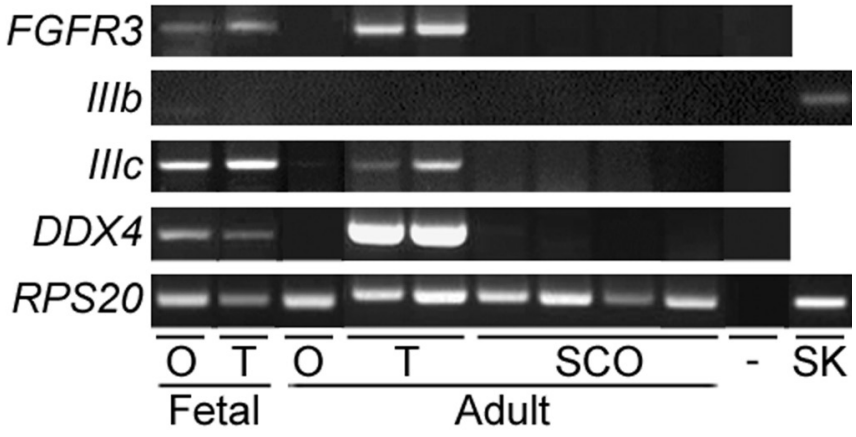

Fig. 1. FGFR3 expression at the mRNA level in human fetal and adult testes and ovaries. RT-PCR showing expression of all FGFR3 splice variants, FGFR3-IIIb (IIIb), FGFR3-IIIC (IIIC), a germ cell marker (DDX4), and a loading control (RPS20) in fetal and adult testis (T) and ovary (O), testis with Sertoli cell-only pattern (SCO), and water (-). Skin (SK) was used as a positive control for FGFR3-IIIb.

van Rhijn et al., 2002). The association of non-skeletal cancers with FGFR3 mutations confirms the potential for a wide range of FGFR3 pleiotropic effects.

Previously, we described a male patient with both achondroplasia (heterozygous for an FGFR3-activating point mutation $1138 \mathrm{G}>\mathrm{A}$ ) and non-mosaic Klinefelter syndrome (47,XXY) (Juul etal., 2007). The loss of sperm production usually associated with Klinefelter syndrome (Aksglæde et al., 2006) appeared partially rescued in this patient and he was able to father a child via a natural fertilization (Juul et al., 2007). Indeed, two other patients with both of these congenital disorders also attained partial rescue of spermatogenesis (oligozoospermia) (Kulakova and Ignat'ev, 1986; Sayli et al., 1994), although this was not always achieved (Sendrail et al., 1967). Nonetheless, the above case stories suggest that activation of FGFR3 is important for achieving normal levels of sperm production. Subsequently, it has been established that FGFR3 is expressed in the spermatogonia in normal human testis (Juul et al., 2007; Goriely et al., 2009; von Kopylow et al., 2010; von Kopylow et al., 2012a), confirming a preliminary finding of an early study (Steger et al., 1998).

Most achondroplasia cases are associated with advanced paternal age at the time of conception of the affected individual (Penrose, 1957). In these sporadic cases, FGFR3-activating mutations occur exclusively in the paternal pre-meiotic germ cells, partly as a consequence of replication errors during spermatogenesis, and are then transmitted to the next generation (Wilkin et al., 1998). Such mutations are thought to impart a selective advantage that results in clonal expansion of the mutant spermatogonia which progresses with age and contributes to the paternal age effect (Goriely \& Wilkie 2012). This hypothesis was strengthened by a study of FGFR3 activity in spermatocytic seminoma (Goriely et al., 2009), a rare germ cell neoplasm which has a late mean age of diagnosis ( $\sim 54$ years) (Eble, 1994) and is thought to be derived from pre-meiotic spermatogonia (Rajpert-De Meyts et al., 2003; Lim et

al., 2011) or primary spermatocytes (Looijenga et al., 2007). Goriely and colleagues showed that FGFR3 is highly expressed in 5/24 spermatocytic seminomas and identified an FGFR3-activating point mutation in two tumours (Goriely et al., 2009).

Collectively, the data outlined above indicate that FGFR3 signalling promotes spermatogonial survival and/or proliferation, and in rare cases of activating mutations in this pathway, may lead to spermatocytic seminoma. It is important to mention in this context that spermatocytic seminoma is a relatively rare type of testicular germ cell tumours (TGCT). Most common TGCT occur in young men and include a variety of histological types, grouped into classical seminoma and nonseminoma, both of which are derived from a fetal gonocyte-like precursor, carcinoma in situ (CIS) testis (Skakkebæk, 1972; Skakkebæk et al., 1987; Sonne et al., 2009). Except for a mutational analysis of FGFR2 and FGFR3 genes (Hansen et al., 2005; Greenman et al., 2007), FGFR signalling has not been studied in these common tumours. Also very little is known about the ontogeny of expression of FGF receptors in the human testis. We hypothesise that FGFR3 signalling may be one of the key pathways involved in normal spermatogenesis and/or the pathogenesis of TGCT. This hypothesis prompted us to investigate the expression pattern of FGFR3 during normal testis development and in germ cell neoplasia, including CIS. We aimed
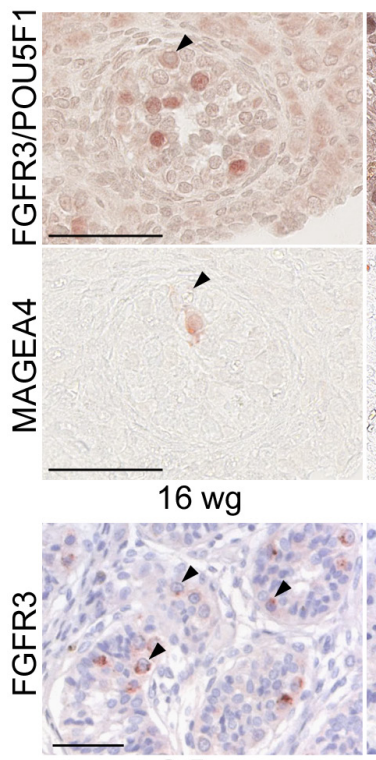

$2.5 \mathrm{~m}$

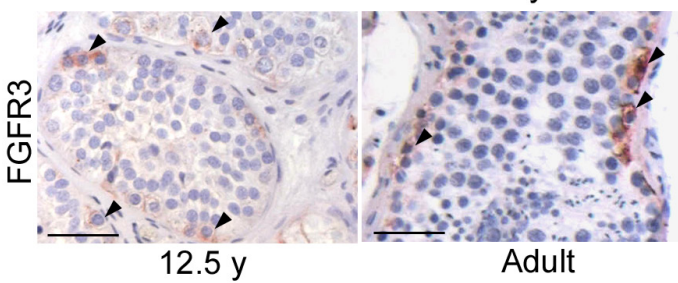

Fig. 2. FGFR3 expression in human testes throughout development. Immunohistochemistry showing expression of FGFR3 (dark blue, cytoplasmic) double stained with a pluripotency marker (POU5F1; red nuclear), FGFR3 alone, and serial sections stained with a spermatogonial marker (MAGEA4, red) in testes of various ages (wg, weeks of gestation; m, months; $y$, years), all sections, except those stained for MAGEA4, counterstained variably with haematoxylin (blue). Arrowheads indicate FGFR3-positive germ cells. Scale bar, $50 \mu \mathrm{m}$. 
TABLE 1

RT-PCR PRIMERS

\begin{tabular}{|c|c|c|c|}
\hline Gene Symbol & Primer Sequence (forward) & Primer Sequence (reverse) & Amplicon (nucleotides) \\
\hline$F_{F G F R 3 \text { (total) }^{a}}$ & ACCTTCAAGCAGCTGGTGGA & CTAGGGACCCCTCACATTGT & 241 \\
\hline FGFR3IIIb & GTGGAGTTCCACTGCAAGGT & GGCTCGACAGAGGTACTCG & 210 \\
\hline FGFR3IIIC & GTGGAGTTCCACTGCAAGGT & GCGTCCTCAAAGGTGACGTT & 191 \\
\hline$D D X 4$ & GTAGTACAAGAGGAAACGTGTT & AGGAGCTATGAGAATGTTAAGTT & 226 \\
\hline RPS20 & AGACTTTGAGAATCACTACAAGA & ATCTGCAATGGTGACTTCCAC & 179 \\
\hline
\end{tabular}

a, this primer pair was designed using exons 16 and 17 from FGFR3 transcript ENST00000260795 in Ensembl (www.ensembl.org) and can detect most FGFR3 transcripts.

to clarify which isoforms/splicing variants of the FGFR3 gene are expressed in the human testis and TGCT, which germ cell and tumour types express FGFR3 and whether the expression is associated with germ cell proliferation.

\section{Results}

Human germ cells express exclusively the FGFR3IIlc isoform

We first analysed FGFR3 mRNA expression in normal human fetal and adult gonads (including samples of testes and ovaries), and in adult testes lacking germ cells, demonstrating the so-called Sertoli-cell-only (SCO) pattern. We performed RT-PCR with primers that recognized all FGFR3 isoforms and primers specific for splice variants FGFR3IIIb and -IIlc (Table 1). Presence of germ cells was confirmed using DDX4 primers and, as expected, SCO testes lacked DDX4 expression (Fig. 1). The epithelial '-IIIb' isoform was detected in skin but not in any gonadal tissues. Total FGFR3 and the mesenchymal '-IIIc' isoform exhibited the same expression profile and were expressed in early fetal gonads of both sexes, but were expressed in a male-specific, germ celldependent manner in adult gonads (Fig. 1). These data indicate that FGFR3IIIc is expressed in fetal gonads and adult testis and is likely restricted to the germline.

\section{FGFR3 protein expression in the testis is specific to fetal pre-spermatogonia and spermatogonia}

Next, we established the spatio-temporal pattern and prevalence of FGFR3 expression in normal human testis throughout development by performing immunohistochemistry (IHC) with two separate antibodies (a monoclonal and a polyclonal) that both recognized both FGFR3 isoforms. To control for the maturation stages of germ cells and Sertoli cells, marker antibodies were used on serial sections and/or using double antibody staining; POU5F1+/ MAGEA4- cells were recognised as gonocytes, spermatogonia of all ages were POU5F1-/MAGEA4+, and AMH marked immature Sertoli cells (Aubry et al., 2003; Rajpert-De Meyts et al., 2004; Honecker et al., 2004; Gaskell et al., 2004).

Both FGFR3 antibodies had identical pattern of positive immuno-staining in skin sections used as a positive control (not shown) and in previously reported (Goriely et al., 2009) FGFR3positive spermatocytic seminomas (an example shown in Fig. 7). However, the fact that other FGF receptors are also expressed in the same pattern in skin, according to The Human Protein Atlas (HPA; www.proteinatlas.org), and that we observed a partly divergent expression pattern in the testis between the two FGFR3 antibodies, led us to test the specificity of the two antibodies by Western blot analysis of adult testis lysates. The monoclonal antibody revealed the mature $(\sim 130 \mathrm{kDa})$ and non-glycosylated $(\sim 100 \mathrm{kDa})$ forms of FGFR3, as well as a degradation product ( $\sim 55 \mathrm{kDa})$ (Supplementary Data S1A). The polyclonal antibody detected not only the $\sim 130, \sim 100$ and $\sim 55 \mathrm{kDa}$ proteins that the monoclonal antibody detected, but also several other $(\sim 120, \sim 80$ and $\sim 50 \mathrm{kDa}$ ) proteins (Supplementary Data S1B). These data indicate that the polyclonal antibody may not be specific for FGFR3 and may recognise additional proteins. Alternatively, some of these additional bands may be FGFR3 epitopes not recognised by the monoclonal antibody. But after extensively comparing the patterns of staining, we consequently relied mainly on the monoclonal antibody or the data that showed an identical pattern between the two antibodies.

The FGFR3 protein was detected by $\mathrm{IHC}$ (using the monoclonal antibody), in the cytoplasm/plasma membrane of very few isolated cells within the testis cords as early as $14 \mathrm{wg}$ (the earliest time point examined). Based on the lack of co-expression of POU5F1, these cells were recognised as pre-spermatogonia, not gonocytes. Interestingly, between 14 and $24 \mathrm{wg}$, a subset of cells within the testis cords expressed FGFR3 independent of both POU5F1 and MAGEA4 (Fig. 2, specimen at 16 w.g.); these cells were consid-
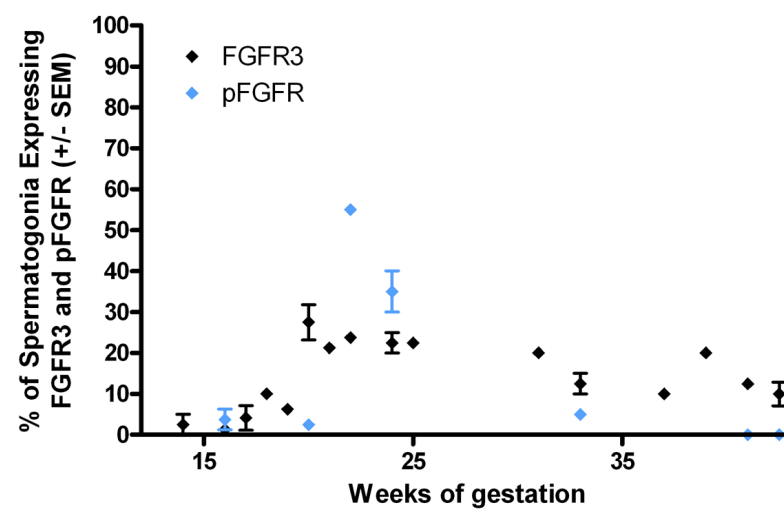

pFGFR

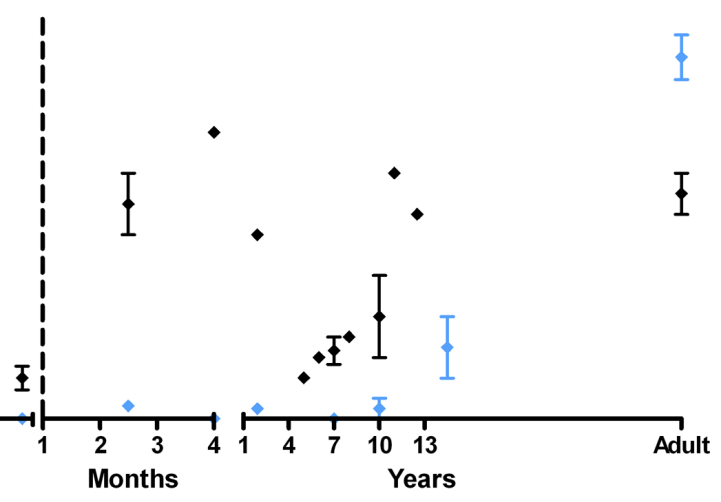

Fig. 3. Prevalence of FGFR3 and phosphorylated ( $p)$ pan-FGFR expression in human spermatogonia throughout development. Quantitative analysis showing the percentage of spermatogonia positive for FGFR3 (black) and p-FGFR (blue) at various time points before and after birth (dashed line). Results are represented as mean values \pm SEM ( $N=1-4$ biological replicates). 
ered to be transitional pre-spermatogonia, as proposed previously (Gaskell et al., 2004). The percentage of FGFR3-positive cells in the testis cords then exhibited three major peaks at mid-gestation ( $\sim 20 \mathrm{wg})$, infancy ( $\sim 4$ months), and from puberty ( $\sim 11$ years) into adulthood whereby expression was maintained in a subpopulation of cells within the seminiferous tubules (Figs. 2 and 3 and Table 2). Based on their location, morphology and co-expression of MAGEA4 the FGFR3-positive cells were considered to be pre-meiotic spermatogonia, most likely type A, both dark and pale (Fig. 2). Absence of FGFR3 expression in a SCO testis at puberty and a fetal ovary at mid-gestation supported this conclusion (Table 2).

\section{FGFR signalling is active in spermatogonia (pre- and post- pubertal)}

To determine if and when FGFR3 signalling is activated in spermatogonia, we performed IHC on testis sections from multiple stages of development using a phospho-specific polyclonal FGFR3 antibody. The specificity of the pFGFR3 antibody was assessed via Western blot analysis, which showed that the mature and non-glycosylated forms of phosphorylated FGFR3 were expressed in normal adult testis, as well as several degradation and/or cleaved products (Supplementary Data S1C). According to the manufacturer, this antibody can cross-react with pFGFR1 and pFGFR2, which share high amino acid sequence homology in the tyrosine kinase domain where the antibody binds. Since we were unable to ascertain whether or not this antibody recognises other FGF receptors, we consider it pan-pFGFR.

A positive reaction for $\mathrm{pFGFR}$ was first detected in isolated cells within the testis cords at $16 \mathrm{wg}$ (the earliest time point examined, because the $14 \mathrm{wg}$ specimen was no longer available); the percentage of pFGFR-positive cells peaked at mid-gestation (22$24 \mathrm{wg}$ ) and increased again from puberty ( 14 years) to adulthood (Figs. 3-4 and Table 2). Prior to adulthood, pFGFR was expressed in the nucleus of infantile pre-spermatogonia and spermatogonia. In the adult testis, pFGFR was expressed in the cytoplasm/plasma membrane of both spermatogonia and Sertoli cells (Fig. 4 and Table 2). These data suggest that FGFR3 signalling is active in infantile and pre-pubertal pre-spermatogonia and is associated with the translocation of the phosphorylated receptor to the nucleus.

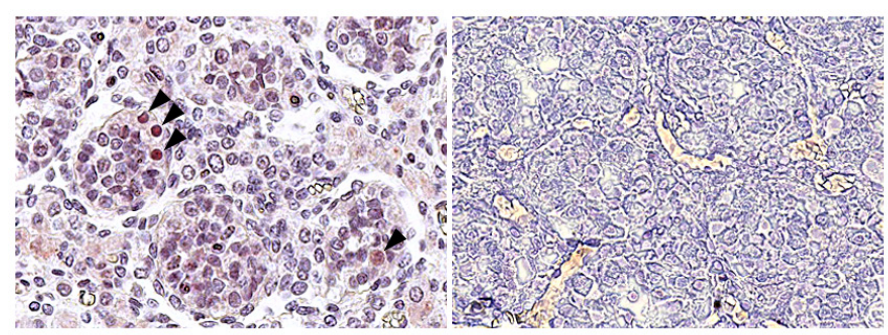

$24 \mathrm{wg}$

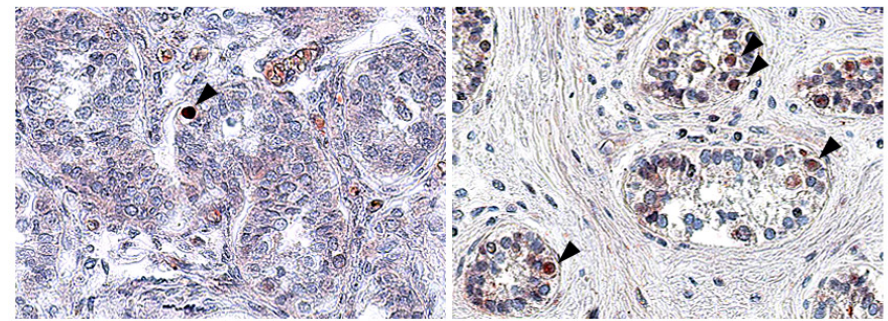

$2.5 \mathrm{~m}$

$10 \mathrm{y}$

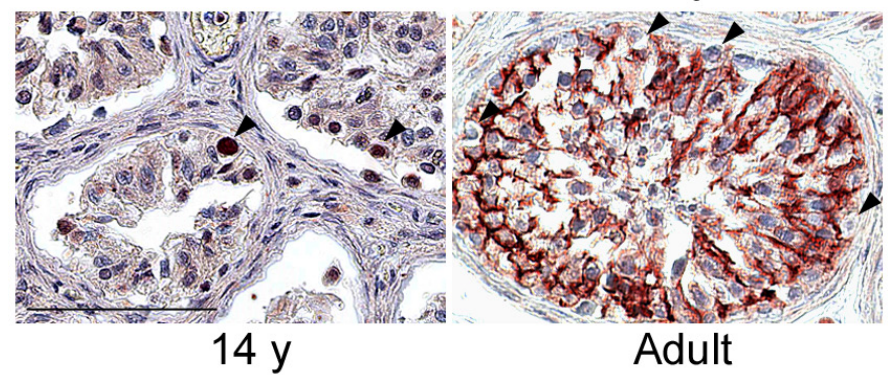

Fig. 4. FGFR signalling activity in human testes throughout development. Immunohistochemistry showing expression of phosphorylated (p)-pan-FGFR in testes of various ages (wg, weeks of gestation; $m$, months; $y$, years), all counterstained with haematoxylin (b/ue). Arrowheads indicate pFGFR-positive germ cells. Scale bar, $100 \mu \mathrm{m}$.

However, from puberty onwards, the phosphorylated protein has a function only on the plasma membrane of spermatogonia. The signal observed in Sertoli cells is likely not from pFGFR3 but from other FGF receptors.

TABLE 2

\section{IMMUNOHISTOCHEMICAL EXPRESSION OF FGFR3 IN HUMAN GONADS THROUGHOUT DEVELOPMENT}

\begin{tabular}{|c|c|c|c|c|c|}
\hline Tissue & Age & $N$ & FGFR3 Staining ${ }^{a}$ & $N$ & pFGFR Staining ${ }^{a}$ \\
\hline \multirow[t]{6}{*}{ Fetal testis } & $14-16 \mathrm{wg}$ & 6 & $\mathrm{GC}+$ to $++($ single cells $-10 \%)$ & 1 & $\mathrm{GC}+($ single cells $)$ \\
\hline & $17-19 w g$ & 6 & $\mathrm{GC}+$ to $++($ single cells $-10 \%)$ & 0 & N.A. \\
\hline & $20-22 \mathrm{wg}$ & 7 & $\mathrm{GC}+/-$ to $+++(10-35 \%)$ & 3 & $\mathrm{GC}+/-$ to $++(5-50 \%)$ \\
\hline & $24-25$ wg & 4 & $\mathrm{GC}+/-$ to $++(10-25 \%)$ & 2 & $\mathrm{GC}+(20-40 \%)$ \\
\hline & $31-33 \mathrm{wg}$ & 4 & $\mathrm{GC}+/-$ to $++(10-20 \%)$ & 1 & $\mathrm{GC}+($ single cells $)$ \\
\hline & $37-41 \mathrm{wg}$ & 3 & $\mathrm{GC}+$ to $+++(10-20 \%)$ & 1 & - (neg.) \\
\hline Fetal ovary & $26 w g$ & 1 & - (neg.) & & N.A. \\
\hline Neonatal testis & $1 d p n$ & 3 & Spg $+(5-15 \%)$ & 2 & - (neg.) \\
\hline Infantile testis & $2 \mathrm{~m}-2 \mathrm{y}$ & 4 & Spg +/- to +++ (45-70\%) & 4 & Spg + to ++ (single cells) \\
\hline Pre-pubertal testis & $5-10 y$ & 8 & Spg + to +++ (10-40\%) & 4 & Spg + to $+++($ single cells $-10 \%)$ \\
\hline Pubertal testis & $11-13 y$ & 2 & Spg +/- to +++ (50-60\%) & & N.A. \\
\hline Pubertal testis & $14 \mathrm{y}$ & 0 & N.A. & 2 & Spg +/- (10-25\%) \\
\hline Pubertal testis (ALL, SCO) & $14 \mathrm{y}$ & 1 & - (neg.) & & N.A. \\
\hline Adult testis & $>25 y$ & 2 & Spg +++ (50-60\%) & 3 & Spg +++ (35-50\%), SC +++ (95\%) \\
\hline
\end{tabular}

a, cell type, staining intensity (-, negative; +/-, very weak staining; +, weak staining; ++, moderate staining; +++, strong staining), and relative number of cells stained.

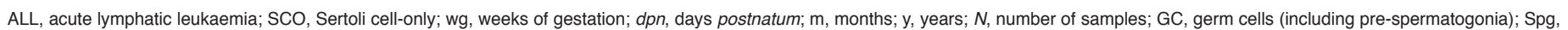
spermatogonia; SC, Sertoli cells; N.A., not analysed. 


\section{FGFR3 expression is not associated with spermatogonial proliferation}

To determine whether FGFR3 signalling controls spermatogonial proliferation, we performed $\mathrm{IHC}$ with antibodies raised against FGFR3 and PCNA or Ki-67 (the former used in Stieve-fluid-fixed samples, the latter in formalin-fixed specimens) on serial sections of testis at multiple developmental time points. The percentage of PCNA-positive germ cells was high at mid-gestation (14$22 \mathrm{wg} ; 70 \sim 80 \%$ ), decreased rapidly by the latter half of gestation (33 wg-1 dpn; 10\%), increased slightly during early infancy ( $\sim 2.5$ months; $\sim 20 \%)$, was low throughout the pre-pubertal period ( $2-7$ years; $<5 \%$ ), and remained elevated (>80\%) in both spermatogonia and spermatocytes in adult testis. The pattern observed in Ki-67-stained specimens was similar but the percentages of positive cells were much lower than PCNA at all ages. Only the specimens from the early gestation (second trimester) had a relatively greater numbers of Ki-67-positive cells. Due to the very low numbers of suitable specimens, it was not possible to quantify the differences. However, close examination of the FGFR3 and proliferation markers showed consistently that they were mutually exclusive in the majority of germ cells at all ages examined (Fig. 5).

\section{FGFR3IIIc mRNA is expressed in testes containing CIS and heterogeneously in TGCTs}

Next, to assess whether FGFR3 is present in testicular germ cell neoplasms arising from CIS, in addition to spermatocytic seminoma (Goriely et al., 2009), we analysed the expression of FGFR3 mRNA in testes that contain CIS and in a variety of TGCTs includ- ing classical and spermatocytic seminomas, embryonal carcinoma and teratoma. We performed RT-PCR using the same FGFR3 and DDX4 primers mentioned above. DDX4 was expressed in all tissues except the teratoma. Expression of DDX4 in two embryonal carcinomas, albeit at reduced levels, may indicate the presence of CIS and/or germ cells in these tissues (Fig. 6). A weak FGFR3IIIb band was detected in some tumour samples, whereas total FGFR3 and FGFR3IIIc were similarly expressed in normal testes, testes containing CIS, and all types of TGCTs, except the teratoma (Fig. 6). Only two (of three) classical seminomas expressed FGFR3 and this heterogeneity was also observed for FGFR3IIlc. These results suggest that FGFR3IIlb expression is likely due to the presence of somatic cells within some tumour samples and that FGFR3IIlc is expressed in CIS and some types of TGCTs.

\section{FGFR3 protein is heterogeneously expressed in CIS and TGCTs}

To confirm these results at the protein level, and determine the cellular localisation of FGFR3 in testes containing CIS and TGCT, we performed IHC with the monoclonal FGFR3 antibody. The presence of CIS was confirmed using an ALPP (PLAP) antibody on serial sections (Fig. 7). In keeping with FGFR3's expression in pre-spermatogonia (but not their precursor cells, gonocytes), the prevalence of FGFR3 expression in CIS was varied but was much less pronounced than that in normal spermatogonia (Fig. 7 and Table 3). FGFR3 was also heterogeneously expressed between the cells of individual tumours, between tumours of the same type, and between different types of TGCTs (Fig. 7 and Table 3). In all instances, FGFR3 was localised to the cytoplasm/plasma mem-

TABLE 3

\section{FGFR3 EXPRESSION IN ADULT TESTES CONTAINING CARCINOMA IN SITU AND TESTICULAR GERM CELL TUMOURS}

\begin{tabular}{|c|c|c|c|}
\hline Tissue histology & $N$ & FGFR3 Staining $^{a}$ & Remarks \\
\hline \multirow[t]{3}{*}{ CIS-only testis } & 3 & CIS - (neg.), Spg + to +++ & No invasive tumour \\
\hline & 4 & CIS - to $+(+<5 \%)$, Spg + to +++ & \\
\hline & 1 & $\mathrm{CIS}+/-$ to $++(90 \%)$ & \\
\hline \multirow[t]{5}{*}{$\mathrm{CIS}$ adjacent to seminoma } & 4 & $\mathrm{CIS}+$ to ++ (single cells), Spg + to ++ & Adjacent to FGFR3+ tumours \\
\hline & 1 & CIS ++ (20\%), Spg + to +++ & Adjacent to FGFR3+ tumour \\
\hline & 2 & $\mathrm{CIS}+(85-95 \%), \mathrm{Spg}++$ to +++ & Adjacent to FGFR3+ tumours \\
\hline & 2 & CIS - (neg.), Spg +/- to +++ & Adjacent to FGFR3-neg. tumours \\
\hline & 1 & $\mathrm{CIS}+(95 \%), \mathrm{Spg}+$ to ++ & Adjacent to FGFR3-neg. tumour \\
\hline \multirow[t]{3}{*}{$\mathrm{CIS}$ adjacent to $\mathrm{EC}$} & 1 & $\mathrm{CIS}+/-$ (single cells), Spg $+/-$ to + & Adjacent to FGFR3+ tumour \\
\hline & 1 & $\mathrm{CIS}+(5 \%), \mathrm{Spg}+$ to ++ & Adjacent to FGFR3-neg. tumour \\
\hline & 4 & $\mathrm{CIS}+/-$ to $++(10-30 \%), \mathrm{Spg}+/-$ to ++ & Adjacent to FGFR3+ tumours \\
\hline \multirow[t]{3}{*}{$\mathrm{CIS}$ adjacent to teratoma } & 1 & $\mathrm{CIS}+/-$ to $+(5-10 \%), \mathrm{Spg}+/-$ to + & Adjacent to FGFR3-neg. tumour \\
\hline & 1 & $\mathrm{CIS}+/-$ to $+(60 \%), \mathrm{Spg}+/-$ to + & Adjacent to FGFR3+ tumour \\
\hline & 1 & $\mathrm{CIS}+$ to $+++(90 \%), \mathrm{Spg}+$ to ++ & Adjacent to FGFR3-neg. tumour \\
\hline $\mathrm{CIS}$ adjacent to mixed non-seminoma & 1 & $\mathrm{CIS}+/-$ to $+(90 \%), \mathrm{Spg}+$ to ++ & Adjacent to FGFR3+ tumour \\
\hline \multirow[t]{2}{*}{ Seminoma } & 10 & $+/-$ to $+++(80-90 \%)$ & \\
\hline & 4 & - (neg.) & \\
\hline \multirow[t]{4}{*}{ EC (embryonal carcinoma) } & 2 & ++ to +++ (single cells) & \\
\hline & 3 & $+/-$ to $++(10-40 \%)$ & \\
\hline & 3 & +/- to +++ $(75-95 \%)$ & \\
\hline & 2 & - (neg.) & \\
\hline \multirow[t]{2}{*}{ Teratoma } & 4 & - (neg.), except cartilage tissue: $+/-$ to ++ & \\
\hline & 3 & - (neg.) & \\
\hline Mixed non-seminoma & 1 & $\mathrm{EC}+/-$ to $+(5 \%), \mathrm{T}$ (skin epithelia): ++ & \\
\hline \multirow[t]{2}{*}{ Spermatocytic seminoma $^{\mathrm{D}}$} & 5 & $++/+(80-100 \%)$ & \\
\hline & 19 & - (neg.) & \\
\hline
\end{tabular}

a Cell type, staining intensity (-, negative; +/-, very weak staining; +, weak staining; ++, moderate staining; +++, strong staining), and relative number of cells stained,

${ }^{\mathrm{b}}$ Reported previously in Goriely et al., 2009. Abbreviations: CIS, carcinoma in situ; N, number of samples; Spg, spermatogonia; EC, embryonal carcinoma; T, teratoma 


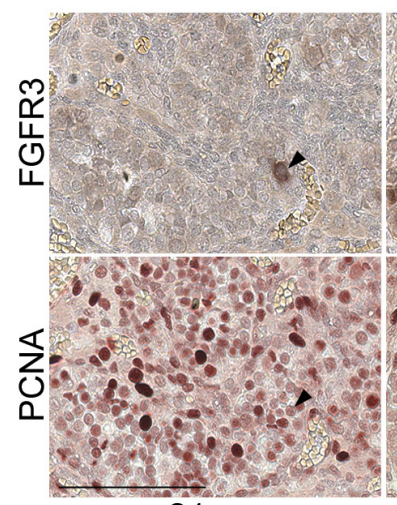

$21 \mathrm{wg}$

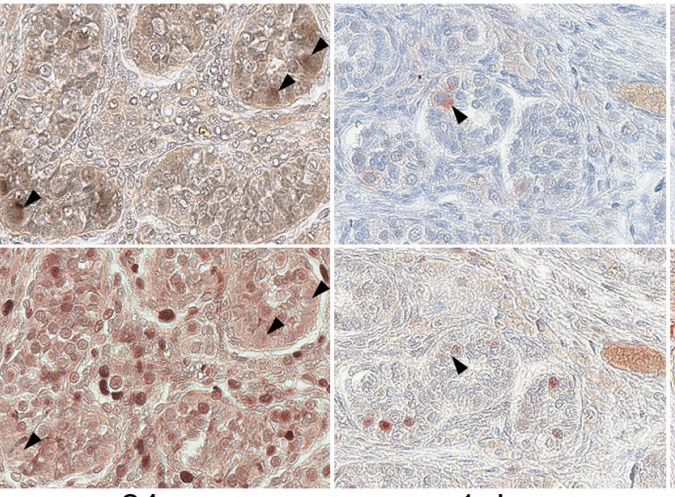

$24 \mathrm{wg}$
$1 \mathrm{dpn}$

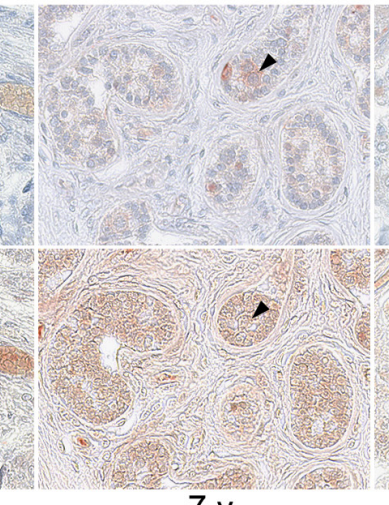

$7 y$

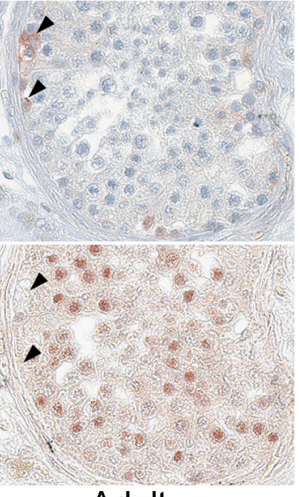

Adult

Fig. 5. Cellular proliferation and FGFR3 expression in human testes throughout development. Immunohistochemistry showing expression of FGFR3 and serial sections stained with a proliferation marker (PCNA) in testes of various ages (wg, weeks of gestation; dpn, days postnatum; y, years), all counterstained with haematoxylin (blue). Arrowheads indicate FGFR3-positive germ cells. Note that FGFR3 is predominantly expressed in the cytoplasm and cell membrane, whereas PCNA is exclusively nuclear. Scale bar, 100 um.

brane. Given a small number of malignant germ cells expressing FGFR3, we did not attempt to analyse the expression of pFGFR. Hence, although FGFR3 is expressed in some CIS and TGCT cells, the ostensibly random nature of this expression pattern draws into question whether FGFR3 signalling plays a role in the pathogenesis of TGCTs arising from CIS.

\section{Discussion}

Our findings demonstrate for the first time that FGFR3 signalling in human male germ cells throughout testis development is mediated exclusively by the 'mesenchymal' FGFR3-IIlc variant. Previously, the FGFR3 variants were only studied in rodents, with some differences between species. A study of murine primordial germ cells (PGC) detected Fgfr1-IIlc and Fgfr2-IIIb but not Fgfr3 (Takeuchi et al., 2005). Studies in the rat detected Fgfr3-IIlc mRNA throughout the testis development (Cancilla \& Risbridger, 1998; Cancilla et al., 2000), while a study in mice reported the presence of mRNA for Fgfr3-IIIb and -IIlc in immuno-purified somatic but not germ cells of fetal XY gonads (Bowles et al., 2010). The Fgfr3 protein product was reported in the cytoplasm of rat fetal germ cells as well as somatic cells, but after puberty the expression was restricted to the cytoplasm of spermatocytes, in a stage dependent manner (Cancilla \& Risbridger, 1998; Cancilla et al., 2000). In the mouse testis, two groups (Schmahl et al., 2004; Willerton et al., 2004) reported Fgfr3 protein expression in the cytoplasm of foetal and pre-pubertal germ and somatic cells, but from prepuberty onwards the expression was restricted to nuclei of spermatogonia. In another mouse study, Fgfr3 was observed mainly in the cytoplasm of PGC, but in induced pluripotent embryonic germ cells (EGC), the protein was detected mainly in the nucleus (Durcova-Hills et al., 2006). In short, these studies suggest that Fgfr3 exhibits a developmentally regulated expression profile in the male germ cells testis that may be unique to each species.

As far as the human testes are concerned, we demonstrate here that FGFR3 is first expressed at the protein level in fetal germ cells after their maturation from gonocytes into pre-spermatogonia. This is consistent with a previous study, which showed that in fetal human testes between 19 and $28 \mathrm{wg}$, FGFR3 is specific to pre-spermatogonia and spermatogonia (von Kopylow et al., 2010). We confirm and extend on these results by defining exactly when FGFR3 is first expressed in the fetal testis and by mapping its expression all the way through development into adulthood. In addition we used spermatogonial, somatic and pluripotency markers to verify that FGFR3 is indeed not expressed in gonocytes. This observation is important, because the gonocyte is a presumed cell of origin of TGCTs that occur in adolescents and young men (Skakkebæk et al., 1987; Sonne et al., 2009), thereby implying that FGFR3 pathway is not likely to be of primary importance for the initiation of these neoplasms.

The FGFR3 expression and activity appears to be partially down-regulated during the second half of gestation and during childhood. By contrast, the FGFR3 expression may be transiently up-regulated in a subset of germ cells at the mini-puberty period in early infancy when there is increased hormonal activity in the pituitary-testis axis. However, these observations are uncertain due to the small number and variable technical quality of these hardto-get human samples. Nevertheless, such a pattern of FGFR3 expression mimics roughly the proliferation profile of germ cells throughout development (Berensztein et al., 2002; Honecker et al.,

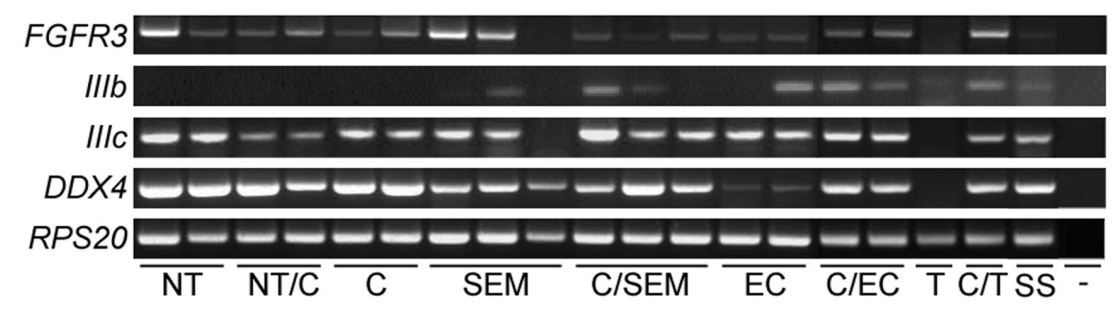

Fig. 6. FGFR3 isoform expression in adult testes containing carcinoma in situ (CIS) and testicular germ cell tumors (TGCTs). RT-PCR showing expression of all FGFR3 splice variants, FGFR3-IIIb (IIIb), FGFR3-IIIc (IIIC), DDX4, and RPS20 in normal adult testis (NT), normal and CIS-containing testis (NT/C), CIS-only testis (C), classical seminoma (SEM), CIS adjacent to SEM (C/SEM), embryonal carcinoma (EC), CIS adjacent to EC (C/EC), teratoma (T), CIS adjacent to T (C/T), spermatocytic seminoma (SS), and water (-). 
2004; Ketola et al., 2003; Müller and Skakkebæk, 1983; Paniagua and Nistal, 1984), prompting us to look into a possible association between FGFR3 expression and cell proliferation. It turned out harder than expected because of the problem with the two proliferation marker antibodies, which were not compatible with both fixatives used to preserve the human tissues. Hence, we could not systematically quantify Ki-67, while PCNA is not a marker of choice for proliferation, since the protein is involved in regulation of the DNA replication, DNA repair, and the maintenance of the chromatin structure (Stoimenov \& Helleday 2009). We observed, however, that the expression of FGFR3 and PCNA/Ki-67 was mutually exclusive in pre-/spermatogonia. Furthermore, although tumourigenesis is a complex, multistep process involving more than just proliferation, it is interesting to note that young men with constitutive activation of FGFR3 do not present with spermatocytic seminomas which originate from spermatogonia (Rajpert-De Meyts et al., 2003), and this mutation is only rarely found in these tumours, and preferentially in relatively older men (Goriely et al., 2009). Thus, FGFR3 signalling before puberty either indirectly stimulates proliferation or, more likely, performs an alternative function, which may lead to an increased spermatogonial survival.

After the onset of puberty and adult spermatogenesis, FGFR3 was in our study present in a subset of germ cells, which we identified as predominantly A-dark spermatogonia but also some A-pale spermatogonia were weakly stained. Spermatocyte nuclei were additionally stained only with the polyclonal antibody, which we deemed less specific. Similarly, in an earlier study using a polyclonal antibody, FGFR3 was identified in the nuclei of all germ cells in the human testis, except elongated spermatids (Steger et al., 1998). More recently, using three different antibodies, including the monoclonal one we employed here, von Kopylow and colleagues, showed FGFR3 to be expressed preferentially in the rarely dividing A-dark spermatogonia (von Kopylow et al., 2012a; 2012b). Collectively these data suggest that FGFR3 in the adult human testis is restricted to spermatogonia $A$ and may have a role in inhibiting rather than promoting their proliferation (von Kopylow et al., 2012b).
In our attempt to localise the active phosphorylated FGFR3 we observed that, while FGFR3 is expressed at the cell surface or cytoplasm of pre-/spermatogonia, the active form of the receptor may be expressed in the nucleus of these cells before birth and puberty and in the cytoplasm of post-pubertal spermatogonia, implicating functional/regulatory differences in this signalling pathway before and after puberty. Interestingly, similar observations have been reported in mice, and in one study, the Fgfr3 protein was upregulated in PGC and apparently translocated into the nucleus upon stimulation with FGF2, which was needed along with LIF to reprogram these cells to pluripotent EGC (DurcovaHills et al., 2006). However, we did not have a possibility to study human PGC, only gonocytes, which are immature germ cells with a high expression of pluripotency factors, but which have already colonised the embryonic testis and are located inside seminiferous cords. We did not detect FGFR3 in fetal gonocytes but first in the next stage in germ cell maturation, pre-spermatogonia, which no longer express pluripotency genes. Thus we believe that the nuclear translocation of activated FGFR3 in the human prepubertal germ cells - if this preliminary observation is confirmed in further studies - is not linked to the regulation of pluripotency genes but another, yet unknown pathway/ biological function, suggesting species differences between humans and mice.

The strong expression of the phosphorylated pan-FGFR but not FGFR3 in Sertoli cells in the adult testis is unexpected and likely represents an active form of one or more of other FGF receptors. The nuclear localisation of a soluble fragment of pFGFR3 after a two-step cleavage of the protein was demonstrated in an in vitro model of FGFR3-transfected COS7 cells (Degnin et al., 2011). It should be noted that, the stoichiometry of phosphorylation at Tyr 724 detected by our pFGFR3 antibody is much lower than the stoichiometry of the other tyrosine residues in FGFR3 (Mohammadi et al., 1996). Hence, this antibody may not provide the best measure of FGFR3 activation, and further expression analysis is needed to clarify the issue of cross-reactivity.

Identifying the ligand/s responsible for activating FGFR3 in pre-/spermatogonia is a high priority, as it/they may regulate
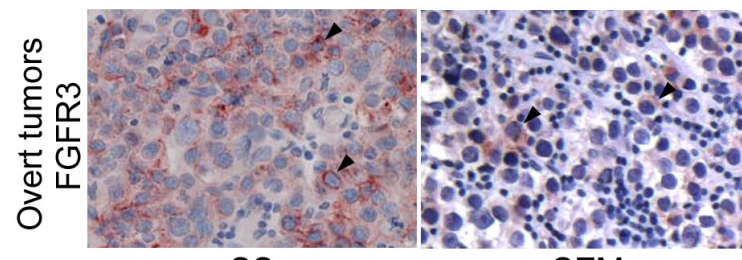
SEM

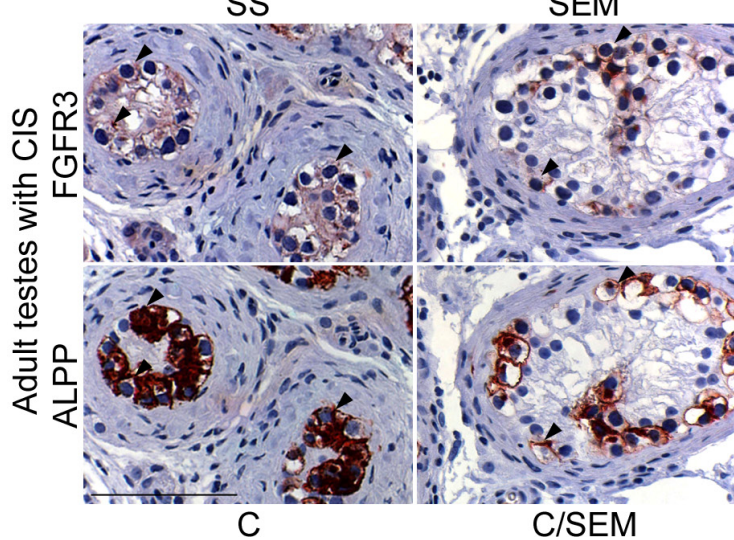

C/SEM
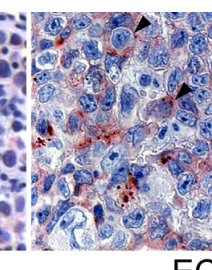
EC

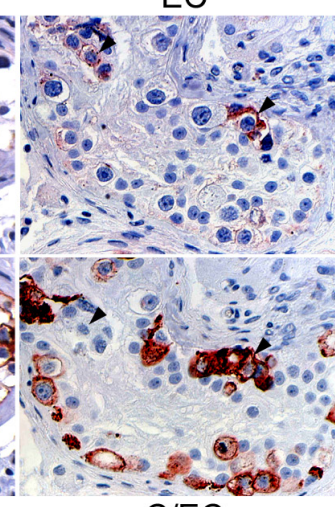

C/EC

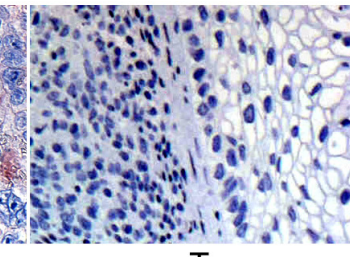

$\mathrm{T}$

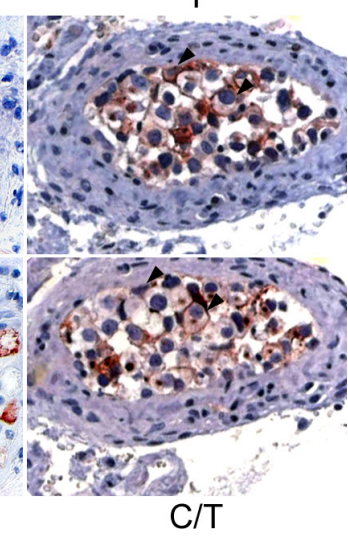

Fig. 7. FGFR3 expression in adult testes containing carcinoma in situ (CIS) and overt testicular germ cell tumors (TGCTs). Immunohistochemistry showing expression of FGFR3 in tissues with CIS and overtTGCTs. To identify CIS cells, serial sections were stained with a marker (ALPP). All sections were counterstained with haematoxylin (b/ue). Arrowheads indicate examples of FGFR3-positive cells. Overt tumours and CIS-containing testes adjacent to an overt tumour were taken from the same testis (where appropriate). Abbreviations: spermatocytic seminoma (SS), classical seminoma (SEM), teratoma (T), CIS-only testis (C), CIS adjacent to SEM (C/SEM), CIS adjacent to $E C(C / E C)$, and $C / S$ adjacent to $T(C / S / T)$. Scale bar, $100 \mu \mathrm{m}$. 
spermatogonial survival or differentiation and could therefore have therapeutic potential. We show that only the FGFR3IIIc isoform is present in human spermatogonia. This information should help narrow down the search for ligand/s responsible for activating the receptor, keeping in mind that multiple different ligands might function at discrete stages of development.

In this study we also investigated common TGCTs derived from CIS that typically occur in young men and found that FGFR3 is expressed in a seemingly random pattern in the precursor CIS and TGCTs. The low expression in CIS is consistent with the idea that CIS is a transformed/mutated gonocyte and is not derived from post-pubertal spermatogonia (Skakkebæk et al., 1987; Sonne et al., 2009). However, the heterogeneous FGFR3 expression in a subset of CIS cells may reflect their plasticity and partial differentiation to more mature phenotype in the adult testis, as previously observed for other proteins (Rajpert-De Meyts et al., 1996; Gueller et al., 2012). Furthermore, no activating mutations in FGF receptor genes in human TGCTs have been detected in comprehensive screens of somatic mutations (Bignell et al., 2006; Greenman et al., 2007). A search for activating mutations in a closely-related gene, FGFR2 in TGCTs and tumour cell lines also failed to detect a mutation (Hansen et al., 2005). Thus we believe that - in contrast to spermatocytic seminoma - the FGFR3 signalling pathway is not likely to be a major contributing factor in the origin of $\mathrm{CIS}$ and the growth control of malignant TGCTs of young men, which are derived from $\mathrm{CIS}$.

In conclusion, this study confirms and extends evidence implicating the involvement of FGFR3 signalling in spermatogenesis. We present evidence that human germ cells express exclusively the FGFR3-IIIc isoform and this variant is male-specific in adult gonads. The protein is expressed and active in pre-spermatogonia but not in gonocytes in the human fetal testis, and later in spermatogonia $A$, and may serve as a marker of these cells. We show that FGFR3 signalling is unlikely to promote proliferation of spermatogonia; instead it may inhibit proliferation and promote survival and/or differentiation of these cells, with likely different functions in preand post-pubertal spermatogonia. Finally, we show that although FGFR3 is expressed in some CIS cells and testicular neoplasms derived from CIS, it is not likely to be a key factor involved in their pathogenesis.

\section{Materials and Methods}

\section{Tissue samples}

The Regional Committee for Medical Research Ethics in Denmark approved the use of human tissues for this project. Fetal gonads at 10-41 weeks of gestation $(\mathrm{wg})$ were isolated from induced or spontaneous abortions and stillborn foetuses that did not show any signs of developmental disorders on autopsy. The methods used to calculate gestational age and sex of the foetuses have been described previously (Jørgensen et al., 1995; Sonne et al., 2009). Fetal gonad samples were either embedded in Optimal Cutting Temperature (OCT) compound (Sakura Fintek Europe, Alphen aan den Rijn, NL) and snap-frozen in isopentane and stored at $-80^{\circ} \mathrm{C}$, or fixed overnight at $4^{\circ} \mathrm{C}$ in Stieve fluid or formalin and then embedded in paraffin. Normal neonatal and postnatal testis specimens were obtained directly after autopsy from individuals who died from causes presumed not to affect testicular development or function, and from boys with acute lymphatic leukaemia (ALL). These testis samples were either snap-frozen or fixed in Stieve's fluid, paraformaldehyde (PFA) or formalin, and paraffin-embedded. All normal fetal and postnatal tissue samples were obtained for previous studies and have been described in detail elsewhere (Jørgensen et al.,
1993; Jørgensen et al., 1995; Rajpert-De Meyts et al., 1999; Sonne et al., 2009). Tissue samples from adult patients lacking germ cells (Sertoli cell-only; SCO), or with testicular neoplasms, were obtained directly after orchidectomy and gross pathological evaluation. Small pieces were then snap-frozen or fixed. The fixatives varied but most of the samples were fixed in Stieve's fluid, modified Stieve's fluid (GR fixative), PFA or formalin, and subsequently paraffin-embedded. Diagnosis of SCO or the TGCT was confirmed by experienced pathologists after histological evaluation of all samples. A biopsy of healthy adult skin was fixed in formalin and then embedded in paraffin as has been described previously (Lange et al., 2001).

For analysis at the gene expression RNA level by reverse transcriptase (RT)-PCR, a panel of five normal gonads were used, including one fetal ovary (10-11 wg), one fetal testis (10-11 wg), one adult ovary and two adult testes, as well as four SCO testes. Normal skin was included in this panel as a positive control for FGFR3-IIlb. A separate series of seven overt TGCTs including three classical seminomas, two embryonal carcinomas, one teratoma and one spermatocytic seminoma, as well as 10 samples of testicular CIS, was also analysed by RT-PCR. Of the $10 \mathrm{CIS}$ testis samples, six were heterogeneous mixes of normal and CIS-containing tubules from tissue adjacent to the included overt tumour (except the spermatocytic seminoma), two were CIS-only and had not progressed to an overt tumour, and two were normal and CIS-containing tubules that had not progressed to an overt tumour. Two normal testis samples were also analysed with this latter series.

For localisation study at the protein level by immunohistochemistry (IHC), a total of 54 normal gonads including one fetal ovary $(26 \mathrm{wg})$ and 53 testes: 30 fetal (14-41 wg), three neonatal (1 day postnatum, dpn), four infantile (2 months - 2 years), eight pre-pubertal (5-10 years), five pubertal (11-14 years, including one with SCO) and three normal adult testes (Table 1). Normal skin was included in this panel as a positive control for all FGFR3 and pFGFR3 antibodies. Two of the normal adult testis samples were also analysed by Western blot.

A second series of 29 overt TGCTs including 14 classical seminomas, 10 embryonal carcinomas, four teratomas and a mixed non-seminoma, as well as 28 samples of testicular CIS, was also analysed by IHC. We included also a tissue array with 24 samples of spermatocytic seminoma, previously used in another study (Goriely et al., 2009). Of the $28 \mathrm{CIS}$ testis samples, 20 were heterogeneous mixes of normal and CIS-containing tubules from tissue adjacent to the included overt tumour, five were CIS-only and had not progressed to an overt tumour, and three were heterogeneous mixes of normal and CIS-containing tubules that had not progressed to an overt tumour (Table 2). It should be noted that, where possible, samples from the same patient were used to perform RT-PCR, Western blotting and IHC.

\section{RNA extraction, RT-PCR, electrophoresis and sequence validation}

RNA was isolated from frozen fetal tissues with the RNAqueous-Micro kit (Ambion, Austin, TX, USA), and from frozen adult testis tissues with the Nucleospin RNAII kit (Macherey-Nagel, Düren, Germany), including DNase I treatment, as described by the manufacturers. In addition, total RNA from human ovary (Ambion) and skin (BioChain Institute Inc., Hayward, CA, USA) was purchased. Samples were quantified using a NanoDrop ND-1000 spectrophotometer (NanoDrop Technologies, Wilmington, DE, USA). One microgram of RNA was reverse transcribed with $A M V$ reverse transcriptase (USB, Cleveland, OH, USA) using a dT20 primer and random hexamers, as described by the manufacturer. PCR experiments were performed thrice with Taq DNA polymerase (GE Healthcare, Buckinghamshire, UK) in a total volume of $30 \mu \mathrm{l}$, using $1 \mu \mathrm{l}$ of cDNA as template or water as a negative control. Specific intron-spanning primers used were designed from Ensemb sequences (www.ensembl.org) for human: total FGFR3 (detects most FGFR3 transcripts), FGFR3IIlb and -IIlc splice variants, DEAD (Asp-GluAla-Asp) box polypeptide 4 (DDX4 or VASA, a marker for both normal and malignant germ cells including CIS), and ribosomal protein S20 (RPS20, a loading control) (Table 3). PCR conditions were: $95^{\circ} \mathrm{C}$ for $3 \mathrm{~min}, 40$ cycles of $95^{\circ} \mathrm{C}$ for $30 \mathrm{~s}, 62^{\circ} \mathrm{C}$ for $30 \mathrm{~s}$, and $72^{\circ} \mathrm{C}$ for $60 \mathrm{~s}$ (except for RPS20, which only cycled 30 times), and then a final extension at $72^{\circ} \mathrm{C}$ for $5 \mathrm{~min}$. PCR 
TABLE 4

PRIMARY ANTIBODY DETAILS FOR IMMUNOHISTOCHEMISTRY

\begin{tabular}{|c|c|c|c|c|c|}
\hline Antigen Name & Source Species & Unmasking Buffer & Dilution & Product Number & Supplier Details \\
\hline FGFR3 & Mouse & TEG pH 9 & $1: 10$ or $1: 50^{b}$ & sc13121 & Santa Cruz Biotechnology \\
\hline FGFR3 & Rabbit & $10 \mathrm{mM}$ citrate $\mathrm{pH} 6$ & $1: 2000$ & sc123 & Santa Cruz Biotechnology \\
\hline pFGFR3 Tyr 724 & Rabbit & TEG pH 9 & $1: 50$ & sc33041 & Santa Cruz Biotechnology \\
\hline POU5F1 & Mouse $^{a}$ & $5 \%$ urea $\mathrm{pH} 8.5$ & $1: 125$ & sc5279 & Santa Cruz Biotechnology \\
\hline POU5F1 & Goat $^{\mathrm{a}}$ & TEG pH 9 & $1: 500$ & sc8629 & Santa Cruz Biotechnology \\
\hline MAGEA4 & Mouse & $10 \mathrm{mM}$ citrate $\mathrm{pH} 6$ & $1: 500$ & - & Gift from G.C. Spagnoli (Univ. Hosp. Zurich, Switzerland) \\
\hline PCNA & Mouse & $10 \mathrm{mM}$ citrate $\mathrm{pH} 6$ & $1: 50$ & M0879 & Dako \\
\hline Ki-67 & Mouse & TEG pH 9 & $1: 100$ & M7240 & Dako \\
\hline AMH & Mouse & $5 \%$ urea $\mathrm{pH} 8.5$ & $1: 150$ & - & Gift from R. Cate (Biogen, Cambridge, MA, USA) \\
\hline ALPP & Mouse & TEG pH 9 & $1: 100$ & M7191 & Dako \\
\hline
\end{tabular}

a POU5F1 (mouse) was used for single antibody staining experiments, POU5F1 (goat) was used for double antibody staining experiments

b 1:10 was used for fetal samples, 1:50 was used for all other samples. TEG, $10 \mathrm{mM}$ Tris + 0.5 mM EGTA

products were loaded on $2 \%$ agarose gels, separated by electrophoresis, and visualized by ethidium bromide staining. Representative images from one of three experiments are presented. Amplified bands, which were of expected sizes (Table 3), were excised. DNA was extracted, using the Nucleospin Extract II kit (Macherey-Nagel) according to the manufacturer's instructions, and sequenced (Eurofins MWG Operon, Ebersberg, Germany). Sequences were verified using Ensembl BLAT analysis (www.ensembl. org/ Homo_sapiens/ blastview).

\section{Immunohistochemistry (IHC)}

The primary antibodies used in this study were raised against the following human antigens: FGFR3 (monoclonal; epitope is amino acids 25-124 which is part of the ligand binding domain; detects both FGFR3-IIlb and -IIlc isoforms), FGFR3 (polyclonal; epitope maps at the $\mathrm{C}$-terminus which is in the tyrosine kinase domain; detects both FGFR3-IIIb and -IIlc isoforms), pFGFR3 (epitope corresponds to phosphorylated Tyr 724 which is in the tyrosine kinase domain; detects active FGFR3), POU class 5 homeobox 1 (POU5F1 or OCT3/4, a marker for pluripotent cells such as primordial germ cells), melanoma antigen family A4 (MAGEA4, a marker for gonocytes and spermatogonia), proliferating cell nuclear antigen (PCNA, a proliferation marker), Ki-67 (a proliferation marker), anti-Müllerian hormone (AMH, a marker for immature/pre-pubertal Sertoli cells, also used to confirm that testis samples were intact, data not shown), and placental alkaline phosphatase (ALPP or PLAP, a marker for TGCTs and CIS in adult testis). See Table 4 for complete primary antibody details. All primary antibodies were diluted in TBS and, for negative controls, serial sections were processed with the primary antibody replaced by TBS alone (these sections were all negative, data not shown). Normal human skin was used as a positive control for the monoclonal and polyclonal FGFR3 and pFGFR3 antibodies (these sections were all positive in the epidermal cell cytoplasm/plasma membrane, data not shown).

For immunohistochemical staining, paraffin embedded tissues were sectioned $(4 \mu \mathrm{m})$ with a microtome onto Superfrost slides. Sections were then dewaxed with Tissue-Clear (Sakura Finetek Europe) and rehydrated through an ethanol series to water. Antigens were unmasked with an appropriate buffer (Table 4) in a microwave oven ( $750 \mathrm{~W}$ for $1 \mathrm{~min}, 300 \mathrm{~W}$ for $15 \mathrm{~min}$ ) and then sections were allowed to cool. All remaining steps were performed at room temperate unless otherwise stated. Endogenous peroxidase activity was quenched with $0.5 \% \mathrm{H}_{2} \mathrm{O}_{2}$ for $10 \mathrm{~min}$. For single antibody staining experiments, IHC was performed using the Histostain-SP kits for either mouse or rabbit (Invitrogen, Taastrup, Denmark) according to the manufacturer's instructions with the following slight modifications: sections were incubated with $10 \%$ non-immune goat serum for 30 min to block unspecific binding sites, with a primary antibody overnight at $4^{\circ} \mathrm{C}$, with either biotinylated goat anti-mouse or biotinylated goat anti-rabbit secondary antibody for $30 \mathrm{~min}$, and then with streptavidin-peroxidase conjugate for $30 \mathrm{~min}$. Bound antibodies were visualized with the aminoethyl carbazole
(AEC) Substrate kit in red (Invitrogen) as described by the manufacturer. For double antibody staining experiments, IHC was performed as follows: sections were incubated with $1 \%$ skim milk block for $30 \mathrm{~min}$, with the first primary antibody overnight at $4^{\circ} \mathrm{C}$, with alkaline phosphatase (AP) conjugated chicken anti-mouse secondary antibody (Abcam, Cambridge, UK) diluted 1:250 for $30 \mathrm{~min}$, with APAAP for mouse (Dako, Glostrup, Denmark) diluted 1:50 for $30 \mathrm{~min}$, and bound antibodies were treated with development buffer for $5 \mathrm{~min}$ and then visualized with 5-bromo-4-chloro-3-indolyl phosphate/nitro blue tetrazolium (BCIP/NBT; Sigma-Aldrich, St Louis, MO, USA) and Levamisol (Sigma) as described in Nielsen et al., (2003). Sections were then incubated with $1 \%$ skim milk block for $30 \mathrm{~min}$, with the second primary antibody overnight at $4^{\circ} \mathrm{C}$, with biotinylated donkey anti-sheep/goat secondary antibody (The Binding Site, Aarhus, Denmark) diluted 1:400 for $30 \mathrm{~min}$, with streptavidin-peroxidase conjugate (Invitrogen) for $30 \mathrm{~min}$, and then bound antibodies were visualized with the AEC Substrate kit in red (Invitrogen) as described by the manufacturer. Sections were washed thoroughly with Tris-buffered saline (TBS; $\mathrm{pH} \mathrm{7.4)} \mathrm{between} \mathrm{each} \mathrm{step,} \mathrm{and}$ finally counterstained with Mayer's haematoxylin and mounted using an aqueous mounting medium. Sections were imaged using a NanoZoomer (Hamamatsu Photonics, Herrsching am Ammersee, Germany) and analysed using NDPview software (Hamamatsu Photonics). IHC experiments were repeated two to four times and representative images are presented. Two observers (KAE and IAO) determined the prevalence (\%) of antibody staining and evaluated the staining intensity, scoring from negative (-) to strong positive (+++).

\section{Protein extraction, SDS-polyacrylamide gel electrophoresis (PAGE) and Western blotting}

Frozen adult testis samples were homogenized on ice in lysis buffer (50 mM Tris- $\mathrm{HCl} \mathrm{pH} \mathrm{7.4,} 100 \mathrm{mM}$ sodium chloride, $2 \mathrm{mM}$ EDTA, 1\% triton X-100, 0.5\% NP-40) with Halt Phosphatase Inhibitor Cocktail (Thermo Scientific, Rockford, IL, USA) and Complete Mini Inhibitor Cocktail EDTAfree (Roche Diagnostics, Indianapolis, IN, USA) added fresh as per the manufacturers' recommendations. Protein was isolated by incubating homogenized tissues in lysis buffer for 2-3 h on ice, vortexing every $20 \mathrm{~min}$. After centrifugation, supernatants were collected and protein concentrations were determined using the Micro BCA Protein Assay kit (Thermo Scientific), as described by the manufacturer, and measured on a Novaspec II spectrophotometer (Pharmacia Biotech, Cambridge, England). Supernatants were then diluted $1: 2$ in SDS Sample Buffer and heated to $95^{\circ} \mathrm{C}$ for $5 \mathrm{~min}$. Proteins $(\sim 20 \mu \mathrm{g})$ were separated under reducing conditions by SDSPAGE with PageRuler Prestained Protein Ladder (Fermentas, Hannover, Germany), as previously described (Sonne et al., 2006). Western transfer, blocking, antibody incubations and membrane colour development with BCIP/NBT were then performed using standard protocols (Sonne et al., 2006). All experiments were repeated at least three times.

Primary antibodies used were raised against FGFR3 (monoclonal), 
FGFR3 (polyclonal) and pFGFR3 (Tyr 724), as detailed in Table 4, diluted $1: 100,1: 200$ and 1:200, respectively. A mouse anti-human $\beta$-actin monoclonal antibody (sc47778; Santa Cruz Biotechnology Inc., Santa Cruz, CA, USA), diluted 1:400, was used as a loading control (data not shown). Secondary antibodies used were AP conjugated chicken anti-mouse (Abcam) and AP conjugated goat anti-rabbit (sc3838; Santa Cruz Biotechnology Inc.), diluted at 1:1000. All antibodies were diluted in 1\% skim milk powder in TBS-Tween $(0.1 \%)$.

\section{Acknowledgements}

The authors wish to thank Brian Vendelbo Hansen and Lene Andersen for excellent technical assistance, Prof. Niels E. Skakkebaek and Dr Martin Blomberg Jensen for helpful discussions, Dr Grete Krag Jacobsen and other pathologists from Rigshospitalet for samples of TGCTs, Prof. Giulio Spagnoli for the MAGE-A4 antibody, Dr. Richard Cate for the AMH antibody, and Prof. Andrew O.M. Wilkie and Dr. Anne Goriely for critical review of the manuscript. The study was supported by a grant from the Danish Cancer Society (DP08147, to ERDM) , the Lundbeck Foundation, and an introductory research stipend from Rigshospitalet (to SBW).

\section{References}

AKSGLÆDE L, WIKSTRÖM AM, RAJPERT-DE MEYTS E, DUNKEL L, SKAKKEB/EK NE, JUUL A (2006). Natural history of seminiferous tubule degeneration in Klinefelter syndrome. Hum Reprod Update 12: 39-48.

AUBRY F, SATIE A-P, RIOUX-LECLERCQ N, RAJPERT-DE MEYTS E, SPAGNOLI GC, CHOMEZ P, DE BACKER O, JEGOU B, SAMSON M (2001). MAGE-A4, a germ-cell specific marker is differentially expressed in testicular tumours. Cancer 902: 2778-2785.

BERENSZTEINEB, SCIARAMI, RIVAROLAMA, BELGOROSKYA (2002). Apoptosis and proliferation of human testicular somatic and germ cells during prepuberty: High rate of testicular growth in newborns mediated by decreased apoptosis. $J$ Clin Endocrinol Metab 87:5113-5118.

BIGNELL G, SMITH R, HUNTER C, STEPHENS P, DAVIES H, GREENMAN C, TEAGUE J, BUTLERA, EDKINS S, STEVENS C et al. (2006). Sequence analysis of the protein kinase gene family in human testicular germ-cell tumors of adolescents and adults. Genes, Chromosomes Cancer 45: 42-46.

BOWLES J, FENG CW, SPILLER C, DAVIDSON TL, JACKSON A, KOOPMAN P (2010). FGF9 suppresses meiosis and promotes male germ cell fate in mice. Dev Cell 19: 440-449.

BRYANT DM, STOW JL (2005). Nuclear translocation of cell-surface receptors: Lessons from fibroblast growth factor. Traffic 6: 947-953.

CANCILLA B, DAVIES A, FORD-PERRISS M, RISBRIDGER GP (2000). Discrete cell- and stage-specific localisation of fibroblast growth factors and receptor expression during testis development. J Endocrinol 164: 149-159.

CANCILLA B, RISBRIDGER GP (1998). Differential localization of fibroblast growth factor receptor-1, $-2,-3$, and -4 in fetal, immature, and adult rat testes. Biol Reprod 58:1138-1145.

CAPPELLEN D, DE OLIVEIRA C, RICOL D, DE MEDINA S, BOURDIN J, SASTREGARAU X, CHOPIN D, THIERY JP, RADVANYI F. (1999). Frequent activating mutations of FGFR3 in human bladder and cervix carcinomas. Nat Genet23: 18-20.

CHESI M, NARDINI E, BRENTS LA, SCHROCK E, RIED T, KUEHL WM, BERGSAGEL PL. (1997) Frequent translocation $\mathrm{t}(4 ; 14)(\mathrm{p} 16.3 ; \mathrm{q} 32.3)$ in multiple myeloma is associated with increased expression and activating mutations of fibroblast growth factor receptor 3. Nat Genet 16: 260-264.

DEGNIN CR, LAEDERICH MB, HORTON WA (2011). Ligand activation leads to regulated intramembrane proteolysis of fibroblast growth factor receptor 3 . Mol Biol Cell. 22:3861-3873.

DURCOVA-HILLSG, ADAMSIR, BARTONSC, SURANIMA, MCLARENA(2006). The role of exogenous fibroblast growth factor-2 on the reprogramming of primordial germ cells into pluripotent stem cells. Stem Cells 24: 1441-1449.

EBLE JN (1994). Spermatocytic seminoma. Hum Pathol 25: 1035-1042.

GASKELL TL, ESNAL A, ROBINSON LL, ANDERSON RA, SAUNDERS PT (2004) Immunohistochemical profiling of germ cells within the human fetal testis: identification of three subpopulations. Biol Reprod 71: 2012-2021.
GORIELY A, HANSEN RMS, TAYLOR IB, OLESEN IA, JACOBSEN GK, MCGOWAN SJ, PFEIFER SP, MCVEAN GAT, RAJPERT-DE MEYTS E, WILKIE AOM (2009). Activating mutations in FGFR3 and HRAS reveal a shared genetic origin for congenital disorders and testicular tumors. Nat Genet 41: 1247-1252.

GORIELY A, WILKIE AO (2012). Paternal age effect mutations and selfish spermatogonial selection: causes and consequences for human disease. Am J Hum Genet 10: 175-200.

GREENMAN C, STEPHENS P, SMITH R, DALGLIESH GL, HUNTER C, BIGNELL G, DAVIES H, TEAGUE J, BUTLER A, STEVENS C et al. (2007). Patterns of somatic mutation in human cancer genomes. Nature 446:153-158.

GUELER B, SONNE SB, ZIMMER J, HILSCHER B, HILSCHER W, GRAEM N, RAJPERT-DE MEYTS E, VOGT PH (2012). AZFa protein DDX3Y is differentially expressed in male germ cells during development and in testicular tumours: new evidence for phenotypic plasticity of germ cells. Hum Reprod; 27: 1547-1555.

HANSEN RMS, GORIELY A, WALL SA, ROBERTS ISD, WILKIE AOM (2005). Fibroblast growth factor receptor 2, gain-of-function mutations, and tumourigenesis: investigating a potential link. J Pathol 207: 27-31

HARADA D, YAMANAKA Y, UEDA K, TANAKA H, SEINO Y (2009). FGFR3-related dwarfism and cell signaling. J Bone Miner Metab 27: 9-15.

HONECKER F, STOOPH, DE KRIJGERRR, LAU YFC, BOKEMEYERC, LOOIJENGA LHJ. (2004) Pathobiological implications of the expression of markers of testicular carcinoma in situ by fetal germ cells. J Pathol 203:849-857.

JOHNSON DE, LU J, CHEN H, WERNER S, WILLIAMS LT (1991). The human fibroblast growth factor receptor genes: a common structural arrangement underlies the mechanisms for generating receptor forms that differ in their third immunoglobulin domain. Mol Cell Biol 11: 4627-4634.

JOHNSON DE, WILLIAMS LT (1992). Structural and functional diversity in the FGF receptor multigene family. Adv Cancer Res 60: 1-41.

JØRGENSEN N, GIWERCMAN A, MÜLLER J, SKAKKEB/EK NE (1993). Immunohistochemical markers of carcinoma in situ of the testis also expressed in normal infantile germ cells. Histopathology 22: 373-378.

JØRGENSEN N, RAJPERT-DE MEYTS E, GRÆM N, MÜLLER J, GIWERCMAN A SKAKKEBEK NE (1995). Expression of immunohistochemical markers for testicular carcinoma in situ by normal human fetal germ cells. Lab Invest72:223-231.

JUUL A, AKSGLÆEE L, LUND AM, DUNO M, SKAKKEBÆEK NE, RAJPERT-DE MEYTS E (2007). Preserved fertility in a non-mosaic Klinefelter patient with a mutation in the fibroblast growth factor receptor 3 gene: Case Report. Hum Reprod 22: 1907-1911.

KETOLAI, TOPPARI J, VASKIVUO T, HERVAR, TAPANAINEN JS, HEIKINHEIMO M (2003). Transcription factor GATA-6, cell proliferation, apoptosis, and apoptosisrelated proteins Bcl-2 and Bax in human fetal testis. J Clin Endocrinol Metab 88: 1858-1865.

KULAKOVA TA, IGNAT'EV I (1986) Achondroplasia associated with Klinefelter's syndrome. Klinicheskaia meditsina 64: 126-128.

LANGE M, THULESEN J, FELDT-RASMUSSEN U, SKAKKEBÆEK NE, VAHL N, JØRGENSEN JO, CHRISTIANSEN JS, POULSEN SS, SNEPPEN SB, JUUL A (2001). Skin morphological changes in growth hormone deficiency and acromegaly. Eur J Endocrinol 145: 147-153

LEE PL, JOHNSON DE, COUSENS LS, FRIED VA, WILLIAMS LT (1989). Purification and complementary DNA cloning of a receptor for basic fibroblast growth factor. Science 245: 57-60.

LIM J, GORIELY A, TURNER GD, EWEN KA, JACOBSEN GK, GRAEM N, WILKIE AO, RAJPERT-DE MEYTS E (2011). OCT2, SSX and SAGE1 reveal the phenotypic heterogeneity of spermatocytic seminoma reflecting distinct subpopulations of spermatogonia. J Pathol 224: 473-83.

LOOIJENGA LH, STOOP H, HERSMUS R, GILLIS AJ, OOSTERHUIS JW (2007) Genomic and expression profiling of human spermatocytic seminomas: pathogenetic implications. Int J Androl 30: 328-335.

MOHAMMADI M, DIKIC I, SOROKIN A, BURGESS WH, JAYE M, SCHLESSINGER $J(1996)$. Identification of six novel autophosphorylation sites on fibroblast growth factor receptor 1 and elucidation of their importance in receptor activation and signal transduction. Mol Cell Biol 16: 977-989.

MÜLLER J, SKAKKEB/EK NE (1983). Quantification of germ cells and seminiferous tubules by stereological examination of testicles from 50 boys who suffered from sudden death. Int $J$ Androl 6:143-156.

NIELSEN JE, HANSEN MA, JØRGENSEN M, TANAKA M, ALMSTRUP K, SKAK- 
KEBFEK NE, LEFFERS H (2003). Germ cell differentiation-dependent and stagespecific expression of LANCL1 in rodent testis. Eur J Histochem 47: 215-222.

ORR-URTREGERA, BEDFORD MT, BURAKOVAT, ARMANE, ZIMMERY, YAYONA, GIVOL D, LONAI P (1993). Developmental localization of the splicing alternatives of fibroblast growth factor receptor-2 (FGFR2). Dev Biol 158: 475-486.

PANIAGUA R, NISTAL M (1984) Morphological and histometric study of human spermatogonia from birth to the onset of puberty. $J$ Anat 139: 535-552.

PENROSE LS (1957). Parental age in achondroplasia and mongolism. Am J Hum Genet 9: 167-169.

RAJPERT-DE MEYTS E, KVIST M, SKAKKEB/EK NE (1996). Heterogeneity of expression of immunohistochemical tumour markers in the testicular carcinoma-in situ: Pathogenetic relevance. Virchows Arch 428: 133-139.

RAJPERT-DE MEYTS E, JØRGENSEN N, GR/EM N, MÜLLER J, CATE RL, SKAKKEBÆEK NE (1999) Expression of anti-Müllerian hormone during normal and pathological gonadal development: Association with differentiation of Sertoli and granulosa cells. J Clin Endocrinol Metab 84: 3836-3844.

RAJPERT-DE MEYTS E, JACOBSEN GK, BARTKOVA J, AUBRY F, SAMSON M, BARTEK J, SKAKKEB/EK NE (2003). The immunohistochemical expression pattern of Chk2, p53, p19INK4d, MAGE-A4 and other selected antigens provides new evidence for the premeiotic origin of spermatocytic seminoma. Histopathology 42: 217-226.

RAJPERT-DE MEYTS E, HANSTEIN R, JØRGENSEN N, GRAM N, VOGT PH, SKAKKEB/EK NE (2004) Developmental expression of the POU5F1 (OCT-3/4) in normal and dysgenetic human gonads. Hum Reprod 19: 1338-1344.

REY, R., AL-ATTAR L, LOUIS F, JAUBERT F, BARBET P, NIHOUL-FEKETE C, CHAUSSAIN JL, JOSSO N (1996). Testicular dysgenesis does not affect expression of anti-mullerian hormone by Sertoli cells in premeiotic seminiferous tubules. Am J Pathol 148: 1689-1698.

RICHELDA R, RONCHETTI D, BALDINI L, CRO L, VIGGIANO L, MARZELLA R, ROCCHI M, OTSUKI T, LOMBARDI L, MAIOLO AT, NERI A (1997). A nove chromosomal translocation $\mathrm{t}(4 ; 14)(\mathrm{p} 16.3$; q32) in multiple myeloma involves the fibroblast growth-factor receptor 3 gene. Blood 90: 4062-4070.

ROBIN NH, FALK MJ, HALDEMAN-ENGLERT CR (1998; updated 2011). FGFRRelated Craniosynostosis Syndromes. In: Pagon RA, Bird TD, Dolan CR, Stephens K, Adam MP, editors. GeneReviews ${ }^{\text {TM }}$ [Internet]. Seattle (WA): University of Washington, Seattle; 1993-. Available from http://www.ncbi.nlm.nih.gov/books/NBK1455/

SAYLI BS, GÜL D, CAKIRBAY H (1994). Achondroplasia with XXY karyotype. Clin Genet 45: 217-218.

SCHMAHL J, KIM Y, COLVIN JS, ORNITZ DM, CAPEL B (2004). Fgf9 induces proliferation and nuclear localization of FGFR2 in Sertoli precursors during male sex determination. Development 131: 3627-3636.

SENDRAIL M, GLEIZES L, SENDRAIL-PESQUÉ M, COLOMBIÉS P (1967). Klinefelter's polygonosomy and achondroplasia. Sem Hop 43: 1217-1225.

SKAKKEB/EK NE (1972). Possible carcinoma-in-situ of the testis. Lancet2: 516-517. SKAKKEB/EKNE, BERTHELSENJG, GIWERCMANA, MÜLLERJ (1987). Carcinoma- in-situ of the testis: possible origin from gonocytes and precursor of all types of germ cell tumours except spermatocytoma. Int J Androl 10,19-28.

SONNE SB, ALMSTRUP K, DALGAARD M, JUNCKER AS, EDSGARD D, RUBAN L, HARRISON NJ, SCHWAGER C, ABDOLLAHI A, HUBER PE, BRUNAK S, GJERDRUMLM, MOORE HD, ANDREWS PW, SKAKKEBAEK NE, RAJPERT-DE MEYTS E, LEFFERS H (2009). Analysis of gene expression profiles of microdissected cell populations indicates that testicular carcinoma in situ is an arrested gonocyte. Cancer Res 69: 5241-5250.

SONNE SB, HOEI-HANSEN CE, NIELSEN JE, HERLIHY AS, ANDERSSON AM, ALMSTRUP K, DAUGAARD G, SKAKKEBFEK NE, LEFFERS H, RAJPERT-DE MEYTSE (2006). CDH1 (E-cadherin) in testicular germ cell neoplasia: Suppressed translation of mRNA in pre-invasive carcinoma in situ but increased protein levels in advanced tumours. APMIS 114: 549-558.

STEGER K, TETENS F, SEITZ J, GROTHE C, BERGMANN M (1998). Localization of fibroblast growth factor 2 (FGF-2) protein and the receptors FGFR 1-4 in normal human seminiferous epithelium. Histochem Cell Biol 110: 57-62.

STOIMENOV I, HELLEDAY T (2009). PCNA on the crossroad of cancer. Biochem Soc Trans 37: 605-613.

TAKEUCHIY, MOLYNEAUXK, RUNYAN C, SCHAIBLE K, WYLIE C (2005). The roles of FGF signaling in germ cell migration in the mouse. Development 132:5399-5409.

VAN RHIJN BWG, VAN TILBORG AAG, LURKIN I, BONAVENTURE J, DE VRIES A, THIERY JP, VAN DER KWAST TH, ZWARTHOFF EC, RADVANYI F (2002). Novel fibroblast growth factor receptor 3 (FGFR3) mutations in bladder cancer previously identified in non-lethal skeletal disorders. Eur J Hum Genet 10:819-824.

VON KOPYLOW K, KIRCHHOFF C, JEZEK D, SCHULZE W, FEIG C, PRIMIG M, STEINKRAUS V, SPIESS AN (2010). Screening for biomarkers of spermatogonia within the human testis: a whole genome approach. Hum Reprod 25: 1104-1112.

VON KOPYLOW K, STAEGE H, SPIESS AN, SCHULZE W, WILL H, PRIMIG M, KIRCHHOFF C (2012a). Differential marker protein expression specifies rarefaction zone-containing human Adark spermatogonia. Reproduction. 143: 45-57.

VON KOPYLOW K, STAEGE H, SCHULZE W, WILL H, KIRCHHOFF C (2012b), Fibroblast growth factor receptor 3 is highly expressed in rarely dividing human type A spermatogonia. Histochem Cell Biol. 138: 759-772.

WELLSA, MARTIU (2002). Signalling shortcuts: Cell-surface receptors in the nucleus? Nat Rev Mol Cell Biol 3: 697-702.

WILKIEAO (2005) Bad bones, absent smell, selfish testes: the pleiotropic consequences of human FGF receptor mutations. Cytokine Growth Factor Rev. 16: 187-203.

WILKIN DJ, SZABO JK, CAMERON R, HENDERSON S, BELLUS GA, MACK ML, KAITILA I, LOUGHLIN J, MUNNICH A, SYKES B, BONAVENTURE J, FRANCOMANO CA (1998). Mutations in fibroblast growth-factor receptor 3 in sporadic cases of achondroplasia occur exclusively on the paternally derived chromosome. Am J Hum Genet 63: 711-716.

WILLERTON L, SMITH RA, RUSSELL D, MACKAY S (2004). Effects of FGF9 on embryonic Sertoli cell proliferation and testicular cord formation in the mouse. Int J Dev Biol 48: 637-643. 


\section{Further Related Reading, published previously in the Int. J. Dev. Biol.}

Identification of side population cells in mouse primordial germ cells and prenatal testis Maria-Lucia Scaldaferri, Stefania Fera, Laura Grisanti, Massimo Sanchez, Mario Stefanini, Massimo De Felici and Elena Vicini Int. J. Dev. Biol. (2011) 55: 209-214

Differentiation of mouse primordial germ cells into female or male germ cells $\mathrm{N}$ Nakatsuji and S Chuma

Int. J. Dev. Biol. (2001) 45: 541-548

The role of stem cell factor and of alternative c-kit gene products in the establishment, maintenance and function of germ cells C Sette, S Dolci, R Geremia and P Rossi Int. J. Dev. Biol. (2000) 44: 599-608

Regulation of primordial germ cell development in the mouse M De Felici

Int. J. Dev. Biol. (2000) 44: 575-580

IGF-I, IGF-II and insulin promote differentiation of spermatogonia to primary spermatocytes in organ culture of newt testes Y Nakayama, T Yamamoto and S I Abé Int. J. Dev. Biol. (1999) 43: 343-347

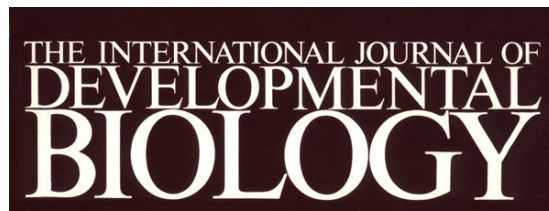

Volume 37 No. 1

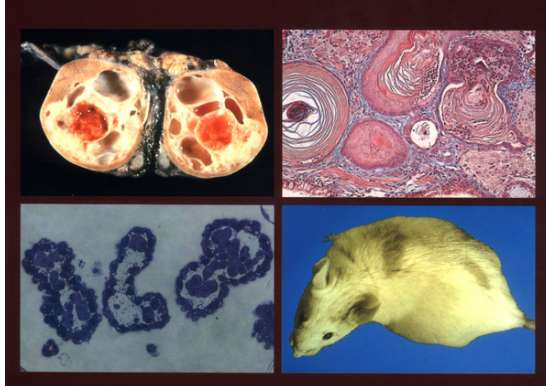

Developmental Aspects of Neoplasia
5 yr ISI Impact Factor $(2011)=2.959$

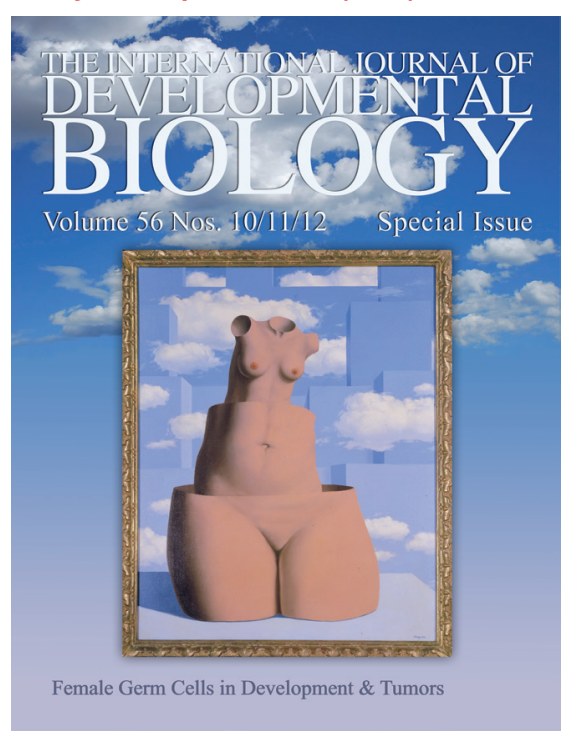

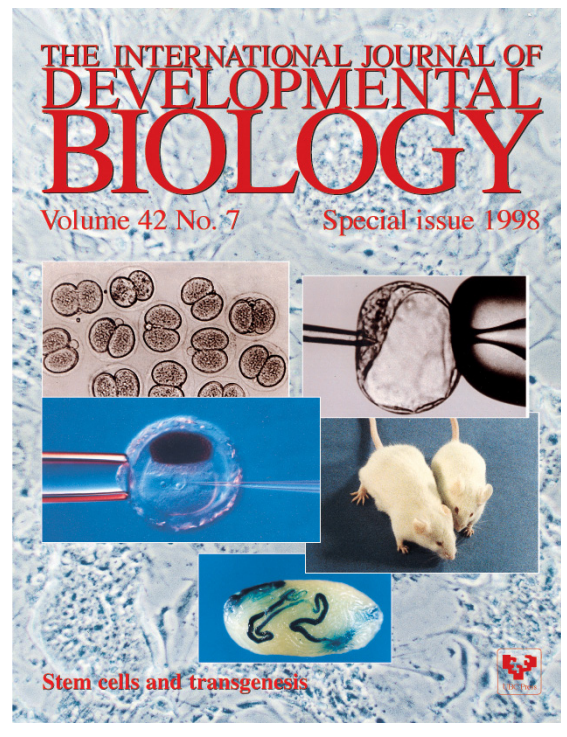

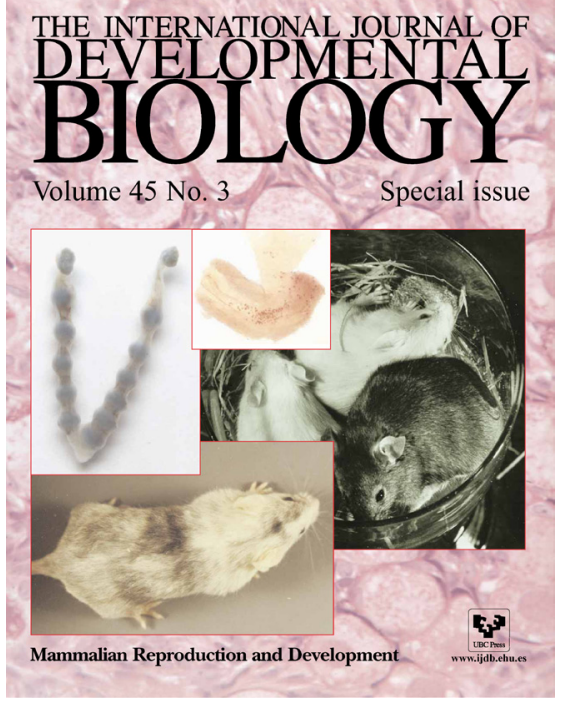

